\title{
The New Killer Pathogens: Bioweapons
}

\section{Chaturvedi S*}

Assistant Professor, Amity University, India

*Corresponding author: Sarika Chaturvedi, Assistant Professor, Biotechnology \& Bioinformatics in Amity Institute of Biotechnology, Amity University, F-406, IRWO Society, Sector 47, Gurgaon - 122001, India, Tel: (+91) 07838931887; Email: sarika.chaturvedi@gmail.com

\section{Mini Review}

Volume 4 Issue 2

Received Date: April 24, 2019

Published Date: May 22, 2019

DOI: $10.23880 /$ oajmb-16000144

\section{Abstract}

Present century requires biological weapons or warfare agents due to several wars and multiple threats. Bioterrorism or biological warfare attack means using microorganism as bacterial, viral agents, toxins or infected samples to cause terror and pose a difficult public health challenge in population (man, animal or plants) when deliberately dispersed in an area. These can cause a large number of casualties, mortality, and morbidity that causes a serious problem in shortest time.

Keywords: Biological Weapons; Microorganism; Clostridium botulinum; Agents

In the ancient history biological weapons had started 14 centuries before Christ to infect besieged city dwellers when Hittites sent infected rams to their enemies and medieval siege of Kaffa, Feodosiya, Ukraine), the Tartars (Mongols) who attacked Kaffa, tossed dead and dying plague victims into the city in an attempt to spread the disease [1].

In 1763 Pontiac's Rebellion near Fort Pitt (present-day Pittsburgh, Pennsylvania) British officers plans to transmit smallpox to Native Americans during the American Revolutionary War (1776-1781). Not sure but smallpox did spread among Natives Americans in the area during and after that rebellion. In 1785 Tunisian forces used plague-tainted clothing as a weapon of La Calle. In Iraq biological weapons discovery was an accidental during release of anthrax from a military testing facility in the former Soviet Union in 1979. In 1930 and 1940s the Sino Japanese war they used plague as biological weapons by filling bombs with plague infected fleas, cholera and shigella as weapons and dropped them from airplanes onto Chinese cities. Approximately 580,000 people died by this [2].
In Fort Pitt, Ohio River Valley, the British troops deliberately spread smallpox among native Indian population by presenting them with blankets and linens used by smallpox victims [3]. Different factors are responsible for the biological warfare agents as accessibility to the agent, scientific expertise to handle and mass produce them and deliver in the proper size for dissemination as aerosol. In USA, Dalles food poisoning is caused by contaminating the salad bars by Salmonella typhimurium. The biological warfare agents are differ from the conventional weapons as they require few hours to weeks before the symptoms appear in the affected population. They are self-replicating entities (Viruses, bacteria, fungi) and having viable materials therefore causing disease in an area so useful as area denial weapons. Toxins (Secondary metabolites) released by bacteria, fungi, algae, plants, fishes, crustaceans and mollusks are also affecting the functioning of cells at very low concentrations. These agents may be developed, acquired or used by national or non-national groups by intelligence or military operation then it can be considered as bioterrorism [4]. 


\section{Open Access Journal of Microbiology \& Biotechnology}

As a biologic warfare agent, Bacillus anthracis is likely to be disseminated through the air (an aerosol). Clostridium botulinum is the pathogenic bacterium that is the causative agent of botulism. Botulism carries a high morbidity and mortality; it is considered a biological warfare agent [5]. Public health authorities classified biological agents on the basis of risk to national security. (i) highest priority with high potential to cause social disruption as these disease agents pose a risk to national security and they can be transmitted from person to person and/or result in high mortality as anthrax, botulism (via botulinum toxin, which is not passable from person to person), plague, smallpox, tularemia, and a collection of viruses that cause hemorrhagic fevers, such as Ebola, Marburg, Lassa, and Machupo. (ii) Agents with low mortality moderately easy to disseminate as brucellosis, glanders, $Q$ fever, ricin toxin, typhus fever, and other agents. (iii) Agents with emerging disease agents that could be engineered for mass dissemination in the future, such as Nipah virus.

The draft Model State Emergency Health Powers Act of 2001, defined bioterrorism as "the intentional use of any microorganism, virus, infectious substance, or biological product that may be engineered as a result of biotechnology, or any naturally occurring or bioengineered component of any such microorganism, virus, infectious substance, or biological product, to cause death, disease, or other biological malfunction in a human, an animal, a plant, or another living organism in order to influence the conduct of government or to intimidate or coerce a civilian population." In 2008 The U.S. Office of the Director of National Intelligence and the National Intelligence Council stated bioterrorism is a more likely threat than nuclear terrorism

\section{References}

1. Christophe G, Cieslak T, Pavlin J, Eitzen E (1997) Biological warfare: A historical perspective. JAMA 278(5): 412-417.

2. McMillan SG, Narin F, Deeds DL (2000) An analysis of the critical role of public science in innovation: the case of biotechnology. Research Policy 29(1): 1-8.

3. Wheelis M (1991) Biological warfare before In: Moon JE van Courtland (Eds.), Biological and toxin weapons: Research, development, and use from the middle ages to 1945. Vol 1 Stockholm, Sweden: Stockholm International Peace Research Institute, pp: 8-34.

4. Wheelis M, Rózsa L, Dando M (2006) Deadly Cultures: Biological Weapons Since 1945. Harvard University Press, pp: 496.

5. Wiener SL (1996) Strategies for the prevention of a successful biological warfare aerosol attack. Mil Med 161(5): 251-256. 